\title{
EVOLUTION AND PERSPECTIVE OF THE TEMPERATE FRUIT CROPS IN SÃO PAULO STATE, BRAZIL ${ }^{1}$
}

\author{
MARCO ANTONIO TECCHIO²; JOSÉ EMILIO BETTIOL NETO², \\ WILSON BARBOSA ${ }^{3}$; MARIA LUIZA SANT’ANA TUCCI ${ }^{4}$
}

ABSTRACT - This work was carried out to show the current situation of the temperate fruit crops in São Paulo state, Brazil, with an emphasis on grapes, peaches, apples, plums, nectarines and pears crops. Current economic data of crops, major growing regions, main cultivars produced, as well as the new technologies generated by research are presented. Regarding the grape crop, a decrease in the national production as well as in the major growing states was observed. The main grapes growing centers in São Paulo state are presented, highlighting its peculiarities regarding cultivars, cultural crop management and current researches. A trend has been observed toward increasing Niagara Rosada grape growing area rather than the fine table grape cultivars. It was also observed the adoption of cultural practices, aiming to increase productivity, to improve the fruits quality and to reduce manpower necessity. In terms of stone fruits, peaches are the most widely cultivated in São Paulo state, followed by plums and nectarines. Both for stone fruits crop and for apples and pears crops, statistics and comments are presented on the crops evolution as well as the current researches results and the requirements of these fruit crops in São Paulo state, Brazil.

Index terms: Temperate fruit crops, economics, diagnosis, cultural management.

\section{EVOLUÇÃO E PERSPECTIVA DA FRUTICULTURA DE CLIMA TEMPERA- DO NO ESTADO DE SÃO PAULO}

RESUMO - Objetiva-se apresentar e discutir a situação atual das principais frutíferas típicas de clima temperado do Estado de São Paulo, como a videira, o pessegueiro, a nectarineira, a ameixeira, a macieira e a pereira. São apresentados os dados econômicos, as principais regiões e cultivares, as novas tecnologias geradas, além de outras pesquisas em desenvolvimento. Na cultura da videira, evidencia-se não somente decréscimo na produção nacional, mas também na maioria dos estados produtores. Apresentam-se os principais polos vitícolas do Estado de São Paulo, com sua particularidade referente às cultivares, manejo cultural e pesquisas de interesse. Nesse sentido, verifica-se a tendência de aumento da área da videira Niagara Rosada em detrimento das cultivares de uva fina de mesa. Evidencia-se, também, a adoção de práticas culturais visando à maior produtividade, qualidade dos frutos e redução na necessidade de mão de obra. Em termos de frutas de caroço, o pessegueiro é o mais cultivado no Estado de São Paulo, seguido pela ameixeira e pela nectarineira. Tanto para as frutas de caroço, quanto para macieira e pereira, são apresentados dados estatísticos e comentários sobre a evolução dessas culturas e os motivos atuais dos sucessos e as principais necessidades da fruticultura temperada no Estado de São Paulo.

Termos para indexação: Fruticultura temperada, economia, diagnóstico, manejo cultural.

\footnotetext{
${ }^{1}$ Palestra Sinfruit 209 - Simpósio Internacional de Fruticultura - Avanços na Fruticultura (17 a 21 Outubro)

${ }^{2}$ Pesquisador Científico do Centro de Frutas, Instituto Agronômico (IAC) - 13214-820 - Jundiaí-SP. Email: tecchio@iac.sp.gov.br; bettiolneto@iac.sp.gov.br

${ }^{3}$ Pesquisador Científico do Centro Experimental Central, Instituto Agronômico (IAC) - Centro Experimental Central - 13075-630 Campinas-SP. Email: wbarbosa@iac.sp.gov.br

${ }^{4}$ Pesquisadora Cientifica do Centro de Horticultura, Instituto Agronômico (IAC) - Centro Experimental Central - 13075-630 - Campinas-SP. Email: tucci@iac.sp.gov.br
} 


\section{INTRODUCTION}

In Brazil 43 million tons of fruits are harvested per year. The state of São Paulo is the largest Brazilian producer, holding $43 \%$ of the total production, that is, about 18.5 million tons (IBRAF, 2010a). Fruit crops industry in São Paulo State is characterized by diversification, by the orchards concentration on family farms, as well as by the intensive use of manpower, with high generation of employments and income (AMARO et al., 2010). According to these authors there is a close relationship between the São Paulo state railroads, such as Companhia Paulista, Central do Brasil and Sorocabana, and the beginning and expansion of fruit growing in the state. It is worth mentioning that the first commercial orchards were planted with temperate fruit crops, mainly due to the colonization by the European and Japanese descendants.

For the last three decades the commercial temperate fruit growing spread out by several regions in São Paulo state, thanks to local research programs, mainly breeding, introduction and evaluation of cultivars and cultivation systems, carried out by Instituto Agronômico (IAC). The results have stimulated farmers to invest in the fruit marketing, diffusing crops such as grapes, stone fruits, as well as other temperate fruit crops. Therefore, many temperate fruit orchards were planted in new nontraditional regions, where very little research has been done regarding climate acclimation and cultural aspects (BARBOSA et al., 2003).

It is worth mentioning that the exchange of information and knowledge among farmers, researchers and extensionists, both from São Paulo state and from other Brazilian regions, was of fundamental importance for the high position of São Paulo state in Brazilian temperate fruit crop industry. Among the temperate fruit crops, grapes and stone fruits are worth mentioning for their economic importance. Nevertheless, other temperate fruit crops such as apple and pear crops are also alternatives to the temperate fruit industry in São Paulo state, mainly in the segment familiar farms, where the product can be marketed in natura or processed within the growing region.

\section{GRAPES CROP}

Brazil is the nineteenth grape producer in the world (FAOSTAT, 2011) with 1,295, 442 tons in 83.718 ha (IBGE, 2011). In 2010 there were a $3.7 \%$ reduction in Brazilian production of grapes when compared to 2009 , the greatest reduction in the states of Bahia and Minas Gerais, being respectively 13.5 and $10 \%$.
São Paulo state grapes production decreased by $3.7 \%$. As for the Brazilian growing area, it decreased by $1.4 \%$ in 2010 when compared to 2009 . São Paulo state has produced 177,934 tons of grapes in 9.514ha, being the second in the Brazilian context, standing out, however as the first Brazilian producer of table grapes (IBGE, 2011). The V. labrusca grapevine 'Niagara Rosada', represents a $48.2 \%$ of grape production and a $89.1 \%$ of the vineyards. Fine table grapes represents a $51.3 \%$ of São Paulo state grapes production, where $0,4 \%$ correspond to cultivars suitable for wine or juice production. In eastern and southwestern São Paulo state the agricultural regions (EDR) of Campinas, Sorocaba and Itapetininga represent $66.8,13.8$ of $10.2 \%$ of the 'Niagara Rosada' production, whereas in northwestern São Paulo state, the agricultural region of Jales represents $2 \%$ of that cultivar production (INSTITUTO DE ECONOMIA AGRÍCOLA, 2011).

In eastern São Paulo state, Jundiaí, Louveira, Indaiatuba, Itupeva, Itatiba, Porto Feliz and Jarinu, stand out as cv. Niagara Rosada producing areas. The predominant type of training is unilateral or bilateral horizontal cordon-training with spur pruning, and the harvest period occurs from December to February. Depending on the environmental conditions, the harvest begins in November in the Indaiatuba County. According to Verdi et al. (2010), in Jundiaí, traditional cv. Niagara Rosada producer, there were 284 grapes growing farms, corresponding to 732.1 ha in 2007/2008. The same authors observed that $92.3 \%, 5.99 \%$ e $0.35 \%$ of the total production corresponded to table grapes, and wine and juice production, respectively. They also concluded that $50 \%$ of the grape growing farms had less than 5 ha and $90 \%$ were below 20 ha.

Regarding the fine table grapes production, it is worth mentioning the southwest and northwest regions of São Paulo state. The agricultural regions (EDR) of Itapetininga, Sorocaba and Jales stand for $82.4 \%$ of grape production (INSTITUTO DE ECONOMIA AGRÍCOLA, 2011) and the vineyards are trained on arbor system. There is predominance of cultivars Italia, Rubi and Benitaka, and to lesser extent cultivars Brasil, Redimeire and Redglobe. The fine seedless table grapes production is based upon the Californian cultivar Centennial Seedless, introduced by IAC in 1988, and to lesser extent, by the Venus grapevine, introduced by EMBRAPA in 1984, as well as by cultivars BRS Clara and BRS Morena, from the EMBRAPA breeding program, available for cultivation in 2003.

In southeastern São Paulo state, São Miguel Arcanjo and Pilar do Sul stant out as grapes produc- 
ers, with predominance of cultivars Itália, Rubi, Benitaka, Brasil, Redglobe and Centennial Seedless, which are harvested from January to April. In the northwestern São Paulo state it is worth mentioning Jales, Urânia, Palmeira d'Oeste, Marinópolis, São Francisco, where fine table grapes are grown, with enphasis in the cultivar Itália and their mutants Rubi, Benitaka, Brasil and Redimeire, as well as cultivars Redglobe and Centennial Seedless. It is noteworthy that the social importance of the regional viticulture is given by the distribution of crop areas primarily in properties of 4-5 ha, with high demand of manpower and income distribution and generation.

Due to the high cost of production of the fine table grape cultivars, coupled with the high demand for labor, supplies, as well as the lower prices in the market, the northwest and southwest regions of the state have shown a decrease in the area planted with these cultivars and a search for alternatives for the region. In fact it has been observed a strong tendency to increase the cv. Niagara Rosada growing area, in view of its good acceptance by the consumer market, the better resale price, higher rusticity of the crop and lower demand for labor. In northwestern São Paulo state, where harvest is held from June to November, off season of Jundiaí County, it is possible to achieve higher prices in the market. There is a high demand of farmers for seedless grapes cultivars more suited to the region, to meet demand of consumer market.

A number of cultural practices have been adopted by farmers aiming to increase the grape business profitability, in view of difficulties such as the high land speculation in the grape growing areas and the shortage of skilled labor. Therefore, as a forecast for the next coming years, we can expect the adoption of new technologies to minimize production costs, by reducing the use of manpower. Changes could be observed in recent years, such as the use of suitable rootstocks for the Niagara Rosada cultivar, the precocious pruning, the adoption of the training ' $\mathrm{Y}$ ' trellis system, the introduction of the rootstock 043-43 aiming to control the soil pearl, the use of plant regulators and the cultivation of grapes for wine production.

Regarding the rootstocks, the 'Ripária do Traviú' tradicionally used in Jundiaí for the Niagara Rosada cultivar, has been replaced because of the soil depletion, by the 'IAC 766', which propitiate the grapes higher vigor, therefore increasing the mineral nutrients requirements.

Noteworthy is also the rootstock pruning, performed in November, the same year of grafting, aiming to anticipate in 6-8 months the first harvest of 'Niagara Rosada'. In the eastern and southeastern São
Paulo state, the early pruning is also frequent, being performed from December to February, allowing grapes to be harvested from April to June, that is, late fall and early winter, when prices are higher, besides providing higher yield in less time. Incorrectly, the early pruning is named 'green pruning' by growers. The climate at the 'early pruning' grapes harvest is more suitable to high quality fruits, once the rainfall is lower and there is a wide temperature range. The early pruning is performed by most growers, and presently 15 to $18 \%$ of Jundiaí and Louveira production of 'Niagara Rosada' cultivar are from vineyards where this kind of pruning has been adopted. Regarding the wine grape production, the system of double pruning has been presenting good results with the 'Syrah' cultivar.

It has recently been observed a significant increase in the adoption by growers of the training Y system for the 'Niagara Rosada', which provides increase productivity, high quality fruits and decreasing manpower use, due to the mechanization of cultural practices. There are a number of references in international literature on the grape training Y system, but in Jundiaí its adoption was intensified from 2006, after a visit of IAC researches to the Empresa de Pesquisa Agropecuária e Extensão Rural de Santa Catarina (EPAGRI). So far, research results indicate that the 'Niagara Rosada' cultivar grafted on the 'IAC 572 ' rootstock has shown better results, in view of the higher vigor that it provides to the scion. Regarding the wine grapes, the use of cordon-training with spur pruning with four wires has shown good results in the experiments carried out in Jundiaí.

With respect to the soil pearls, one of the main grapevine diseases in São Paulo state, alternatives have been sought for its control, once the use of insecticides has been proved economically unfeasible. Recent experiments with rootstocks resistant to soil pearls like the 043-43, coupled with soil proper management, have been showing promising results, but further experimentation is necessary to evaluate the aspects related to the productivity of Niagara Rosada cultivar, grafted on 043-43.

Regarding the cultivation of grapes for wine or juice production, researches with cultivars adapted to the regional edaphic conditions are required as well as evaluations of these cultivars on different rootstocks. Grape growers in Jundiaí, have been searching for adding value alternatives, to the grape growing, generally by association of wine or juice grapes cultivation and the rural tourism. Among the current most planted wine grape cultivars are Seibel-2, Isabel, Bordô, IAC 13822 Máximo and Moscatel. The diagnoses, performed by Verdi et al. (2010), indicated also a slight increase 
in the cultivation of wine grapes such as 'Cabernet Sauvignon', 'Merlot' and 'Syrah' and higher increase of the hybrid cultivars IAC 138-22 'Máximo' and 'Moscatel' which stand for 18.5 and $11.4 \%$, respectively of the new growing area.

Among the main technological changes for the grape cultivation in the northwestern region are the use of the Sombrite-like plastic covering, aiming the hail protection and bird attacks; the practice of pruning the vineyard twice a year, that is a formation pruning from July to November, and a production pruning from February to June; the aerial grafting carried out from 40 to $60 \mathrm{~cm}$ from the soil level. It is also worth mentioning the technological advances with the use of plant regulators, with emphasis to the experiments using ethephon with the aim of improving the emission of new buds (Fracaro \& Pereira, 2004) and increase the Niagara Rosada cultivar productivity (Fracaro et al., 2004). Note worthy is that the 'Niagara Rosada' cultivar grown in the region presents an uneven bud burst and the development of after pruning sprouts, mainly when pruning is carried out from May to June, under temperatures below $10^{\circ} \mathrm{C}$. The application of giberelic acid and thidiazuron to increase bunches and berries size of 'Niagara Rosada' cultivar is also a practice widely use by growers. Botelho et al. (2004) verified an increase in weight and size of the 'Niagara Rosada' cultivar berries, by using $5 \mathrm{mg} \mathrm{L}^{-1}$ thidiazuron in association or not with $35 \mathrm{mg} \mathrm{L}^{-1}$ giberelic acid.

It is important to mention the importance of the experiments with plant regulators aiming to reduce grapes post-harvest losses. Tecchio et al. (2009) verified a significant reduction in losses by berries dropping and in the incidence in the 'Niagara Rosada' cultivar diseases, by the use of $100 \mathrm{mg} \mathrm{L}^{-1}$ naftalen acetic acid. However, for the adoption of the practice the search for cheaper products is required.

Regarding the grapevine dormancy break and budding standardization, products containing cyanamide are usually recommended in Brazil. However, the Environment Protection Agency has classified this product as highly toxic, and the search for other products is required. Therefore, aiming to find natural products to replace the cyanamide use for dormancy bud breaking, the study of the effect of other products is required, as for instance the garlic extract that has been presenting positive results according to Botelho et al. (2010).

Another important research area that could be prioritized is the wine, as well as table grape and rootstocks germplasm collection characterization. It is also important to improve the germplasm collections by the introduction of new species and varieties. Currently the Centro de Frutas, of Instituto Agronômico (IAC) has about 360 varieties and/or accesses in its gemplasm collection. Germplasm conservation and characterization are essential to the present of future use of the genetic variability of the species, as well as to the development of new varieties to meet demand of market, as well as new varieties resistant to pests and diseases in order to decrease the use of agrochemicals. From 1993, with the establishment of the Estação Experimental de Viticultura Tropical, da Embrapa Uva e Vinho, studies have been carried out, on the grapevine breeding aiming to obtain apirenic grapes cultivars, as well as rustic table and processing grapes suitable to the climate conditions of the northwestern São Paulo state. As a result the apirenic table grapes BRS Clara, BRS Linda and BRS Morena and the processing cultivars BRS Cora, BRS Violeta, BRS Carmen, BRS Lorena, BRS Margot and Moscato Embrapa were developed (MARTINS et al., 2010).

\section{STONE FRUITS (PEACH, NECTARINE AND PLUM)}

Peach crop growing area in Brazil, according to IBGE (2011) increased from 17.5 thousand ha in 1996 to 22.5 thousand ha in 2007, decreasing to 19.1 mil ha in 2009 , oscillating during the period, with slight annual variations. Presently, in Brasil the peach is one of the fruits with higher number of commercial varieties. The IAC has developed and made available to farmers from São Paulo state as well as from the neighbour states a dozen cultivars presenting many characteristics of climate adaptability, types of fruits, harvest seasons, and commercial destinations (processing or in natura consumption) among others. The cultivars and selections developed by IAC, as well as their major characteristics were gathered by researchers of Centro de Frutas (BARBOSA et al., 2010). The diversity of characteristics of this wide range of available cultivars, results in high profitability for the grower, even though some of them are marketed at the same time. The reason is that some kinds of fruits are more in demand than others, because of consumer's preferences, resulting in higher prices (ALMEIDA, 2006).

In São Paulo state there are two major regions of stone fruits production, the first one next to the region of São Paulo capital, corresponding to Guapiara, Mairinque, Mogi das Cruzes, Valinhos, Jundiaí and Atibaia. The other one corresponds to the Botucatu region, extending from Itapetininga to Paranapanema, standing for $45 \%$ of the total area and for $40 \%$ of the stone fruits production in the state (peaches, nectarines and plums), and for 33\% 
of the area in expansion with these crops (IBRAF, 2010b). According to LUPA (2008), the stone fruits crop growing areas are about 2,265, 324 and 1,167 ha, cultivated with peaches, nectarines and plums 833, 105 and 358 farms, respectively.

The cultivar is one or the major components of the production system, and one of the few that can be modified without changing the orchard production cost (MEDEIROS, 2005). The peach Aurora-1 (IAC 680-179) cultivar is the only one recommended for commercial growing in Jaboticabal region, because of its high adaptation to the warmer climate, the precocity of its production cycle and the high quality of its fruits (PEREIRA, 2003). So, it is evident that one of the main demands for researching on peach and nectarine crops concerns the development of cultivars with low cold requirement for dormancy breaking, as well as the production in the subtropical regions. Despite the wide cultivars diversity available in São Paulo state and the efforts of the researches, it is necessary to organize and to integrate the institutional programs aiming to improve both human and material labor conditions. So, it will be possible the development of new relevant researches, aiming to make available for the region, new selections of high agronomical value. The support and integration of government institutions certainly will boost the crops development in the context of management techniques for growing temperate fruits in warmer climate regions. That is important once temperate fruits growing under warmer climate conditions could be marketed earlier, and so could reach higher prices. Other agronomic traits have been highly sought after by the market and so, have been examined by the government research institutes: lager and intensively flavored fruits, earlier harvested, colorful and round shaped fruits, firm non-melting flesh, and highly resistant to diseases and pests.

Regarding plums, despite the development of national cultivars, which have allowed a wider range of harvest seasons, Brazil so far needs to import temperate fruits mainly from Chile and Argentina. The Brazilian consumption of plums is about 50 thousand tons per year, mainly from Prunus salicina Lindl. According to Bettiol Neto et al. (2010), the production of plums in São Paulo state is based on cultivars introduced from South Africa and studied at IAC, 'Reubennel' and 'Harry Pickestone', being the most widely cultivated for the last two decades. Once these cultivars are properly adapted to the climate of São Paulo state and produce high quality fruits, they have been successful throughout the productive plum chain. The same authors have alerted to the severe damages caused to the species by Xyllella fastidiosa, the agent of the serious disease known as leaves scald, which has caused the eradication of plum orchards in some plum growing regions in São Paulo state. Therefore, the possibility of finding a way that allowed the coexistence plant/disease, as well as the identification and management of the bacteria leafhopper vector would meet growers demand. As for the development of resistant cultivars it would not be feasible in short term.

There is a lack of improved cultivars to be adapted in warmer regions, with few hours cold in the winter. Noteworthy is the case of plum cultivation in an altitude tropical climate, in Mucugê (BA), Brazil $\left(13^{\circ} 00^{\prime} \mathrm{S}, 41^{\circ} 22^{\prime} \mathrm{W}\right.$. altitude $\left.980 \mathrm{~m}\right)$, where plants develop and produce well, even in climate conditions never before contemplated (BARBOSA, 2006).

Besides the cultivar the seedling quality is one of the main factors to be observed to build an orchard properly. Therefore, rootstocks characteristics such as compatibility, rootstocks resistance or tolerance to the main nematodes species, amount and proper distribution of roots, among others are of fundamental importance. The major contribution to the peaches and plums rootstocks in Brazil was the introduction of the cultivar Okinawa [Prunus persica (L.) Batsch], in 1969 , by IAC, once it has become the most used in São Paulo state, due to its resistance to nematodes of genus Meloidogyne (MALO, 1967). Recent studies have shown its high performance, mainly under the cultivar Aurora-1, from the Japanese Clon-10 introduced by IAC and made available under the name of 'Rigitano' (PEREIRA et al, 2007). The species, besides the already mentioned characteristics, presents the advantage of inducing dwarfism in peach trees, the possibility of producing larger fruits, with higher amount of soluble solids, and to highlight the red pigment of the skin, making it a promising rootstock for dense crop stands. So, the lack of rootstocks cultivars for stone fruits indicates that there is a wide range of research to be developed on the subject.

\section{POMOIDEA-PEARAND APPLE CROPS}

Pears are the third most consumed temperate fruit in Brazil, behind apples and grapes. The annual production of pears is about 18-20 thousand tons, and consumption is almost eight times higher, what makes the product dependent on imports $(85-90 \%)$, to meet Brazilian demand (IBGE, 2009).

The growing areas in Brazil are concentrated in the states of Rio Grande do Sul, Santa Catarina, Paraná and São Paulo and harvests occur from February to April (Faoro e Orth, 2010). In São Paulo state, 139 farms stand for about 191 ha cultivated with pears (LUPA, 2008), but the supply is too low 
to meet demand in the state.

The breeding research program at Instituto Agronômico (IAC), with species and cultivars adapted to subtropical climate, allows the expansion of pear cultivation to regions of mild winter (BARBOSA et al., 2007). The cultivar IAC 16-30, named 'Princesinha', has shown high performance in Vale do São Francisco irrigated areas under climate characteristics, mainly low temperatures, below those required by the crop and besides that, with a perspective of harvesting throughout the year.

As technological advances are being achieved, both through new cultivars and modern cultivation techniques, the perspective for the pear crop becomes very promising, and, like the case of apples, the pears supply can exceed domestic demand, reversing the Brazilian condition from importing to exporter.

It has long been known the cultivation of rustic pears in São Paulo state, but their fruits are worse in quality and flavor, in comparison with European pears, whose cold requirements are high, so that they do not show high performances in São Paulo state climate conditions. Despite the efforts in obtaining high quality selections, climate adapted, and the availability of cultivars with commercial potential, poor acceptation of these cultivars has been observed among growers. Recently, in 2007, aiming to meet demand two IAC cultivars were made available to farmers: 'Princesinha' (IAC16-30) and 'Culinária' (IAC16-41), the first for consumption in natura, and the other for processing. So, there is a demand for precocious cultivars, adapted to climate, and whenever possible resistant to major pests and crop diseases. Researches on oriental rootstocks or on interspecific grafting, resulting dwarfism and the use of plant regulators in pear trees should deserve special attention in the new projects. It is known the viability of crosses between European and Asiatic pears, whose selected descendants were successfully tested in warmer São Paulo state regions like (BARBOSA et al., 2007).

Analyzing the evolution of the apple crop in Brazil, Fioravanço (2009) observed an increase of $1.204 \%$ in the growing area and of $3.446 \%$ in fruits production. The author identified two distinct periods: from 1970 to 1981, small production increase; from 1981 to 2000, a period of wide crop expansion, characterized by the increase in the growing área, participation in the sector, of large companies and small farmers, increase in productivity and improvement of quality by means of the improvement of the productive process and, from 2000 , there was a decrease in production even with the increase of the growing area, pointing to the orchards renewal or even to the productive sector actions to limit yield aiming to favor fruits quality. As for exports, have been consolidated since 1999, reaching a peak in 2004, with estimate volume about 153 thousand tons (FIORAVANÇO, 2009).

In São Paulo state the apple crop is limited to 151 ha in 47 farms (LUPA, 2008). The crop area represents only $0.4 \%$, of the Brazilian apple growing área which is limits mainly in Brazilian southern states. However, as the various segments involved in the apple productive chain are organized, and are developed production technologies adapted to the São Paulo state conditions, it the crop expansion in the state will be possible, making it a feasible alternative of income to growers. São Paulo state has in comparison to the main apple producers Brazilian states, the advantage of harvest anticipation, which propitiate higher prices in the market. In the last years 70 e 80, many apple producers in São Paulo state had high income growing early apples, harvested in November and December. Otherwise the growers have to face the unfair competition with the production from Santa Catarina, where the climate is more suitable for apple growing. Currently the 'Eva' cultivar, developed by IAPAR, has been stimulating the plantation of new orchards in some regions of the state with promising results. So, the demand for researches on the apple tree is very similar to that of the pear tree, as for the need of early cultivars, high quality and more adapted to the climate conditions of São Paulo state.

\section{REFERENCES}

ALMEIDA, G.V.B. de; DURIGAN, J.F. Relação entre as características químicas e o valor dos pêssegos comercializados pelo sistema Veiling frutas Holambra em Paranapanema-SP. Revista Brasileira de Fruticultura, Jaboticabal, v.28, n.2, p.218-221, 2006.

AMARO, A. A.; FAGUNDES, P. R. S.; ALMEIDA, G. V. B. Importância econômica da fruticultura. In: DONADIO, L. C. História da fruticultura paulista. Jaboticabal: Sociedade Brasileira de Fruticultura, 2010. p. 14-32.

BARBOSA, W. Gulfblaze: nova opção de ameixa para o Estado de São Paulo. 2006. Disponível em: $<$ http://www.infobibos.com/Artigos/Ameixa/Ameixa.htm>. Acesso em: maio 2011. 
BARBOSA, W.; POMMER, C. V.; RIBEIRO, M. D.; VEIGA, R. F. A; COSTA. A. A. Distribuição geográfica e diversidade varietal de frutíferas e nozes de clima temperado no Estado de São Paulo. Revista Brasileira de Fruticultura, Jaboticabal, v.25, n.2, p.341-344, 2003.

BARBOSA, W.; POMMER, C.V.; TOMBOLATO, A.F.C.; MELETTI, L.M.M.; VEIGA, R.F. de A.; MOURA, M.M.; PIO, R. Asian pear tree breeding for subtropical areas of Brazil. Fruits, Paris, v.62, p.21-26, 2007.

BARBOSA, W.; BETTIOL NETO, J. E.; DALLORTO, F. A. C.; TECCHIO, M. A. . Pêssego e Nectarina. In: DONADIO, L. C. História da fruticultura paulista. Jaboticabal: Sociedade Brasileira de Fruticultura, 2010. p. 285-302.

BETTIOL NETO, J. E.; BARBOSA, W; DALLORTO, F. A. C. Ameixa. In: DONADIO, L. C. História da fruticultura paulista. Jaboticabal: Sociedade Brasileira de Fruticultura, 2010. p. 84-92.

BOTELHO, R. V.; PIRES, E. J. P.; TERRA, M. $M$. Efeitos de reguladores vegetais na qualidade de uvas 'Niagara Rosada' na região noroeste do Estado de São Paulo. Revista Brasileira de Fruticultura, Jaboticabal, v. 26, n. 1, p. 74-77, 2004.

BOTELHO, R. V.; PIRES, E. J. P.; MOURA, M. F.; TERRA, M. A.; TECCHIO, M. A. Garlic extract improves budbreak of the 'Niagara Rosada' grapevines on sub-tropical regions. Ciência Rural, Santa Maria, v. 40 , n. 11, p. $2282-2287,2010$.

CHAGAS, E. A.; CAMPO DALL'ORTO, F. A.; OJIMA, M.; BARBOSA, W.; PIO, R. Pear IAC Princesinha: new european type cultivar for subtropical climate. In: INTERNACIONAL PEAR SYMPOSIUM, 10., 2007, Peniche. Proceedings...

CHAGAS, E. A.; CAMPO DALL'ORTO, F. A.; OJIMA, M.; BARBOSA, W.; PIO, R. Pear IAC Culinária: new canning cultivar, european type, for subtropical climate. In: INTERNACIONAL PEAR SYMPOSIUM, 10., 2007, Peniche. Proceedings...

FAORO, I.D.; ORTH, A.I. Qualidade de frutos da pereira-japonesa colhidos em duas regiões de Santa Catarina, Brasil. Revista Brasileira de Fruticultura, Jaboticabal, v. 32, n.1, p.308-315, 2010.
FRACARO, A. A.; PEREIRA, F. M. Efeito do ethephon sobre a brotação e vigor dos ramos da videira 'Niagara Rosada' (Vitis labrusca L.). Revista Brasileira de Fruticultura, Jaboticabal, v. 26, n. 3 , p.399-402, 2004.

FRACARO, A. A.; PEREIRA, F. M.; NACHTIGAL, J. C.; BARBOSA, J. C. Efeito do ethephon sobre a produção da uva 'Niagara Rosada' (Vitis labrusca L.), produzida na entressafra na região de Jales-SP. Revista Brasileira de Fruticultura, Jaboticabal, v. 26, n. 1, 82-85, 2004.

FAO. Faostat agriculture data - croops and processed - grape and wine. Disponível em: $<\mathrm{http} / /$ www.faostat.fao.org>. Acesso em: maio 2011.

FIORAVANÇO, J. C. Maçã brasileira: da importação à autossuficiência e exportação - a tecnologia como fator determinante. Informações Econômicas, São Paulo, v.39, n.3, p.56-67, 2009.

IBRAF - Instituto Brasileiro de Frutas. Frutas brasileiras em ascensão. Disponível em: $<\mathrm{http}: / \mathrm{www}$. ibraf.org.br/imprensa/0901 FrutasBrasileirasAscensao.asp> Acesso em: 02 maio 2011.

IBRAF - Instituto Brasileiro de Frutas. O projeto fruta paulista. Disponível em: $<$ http://www.ibraf. org.br/frutassaude/frutaPaulista.asp\#regioes $>$. Acesso em: 04 maio 2011.

IBGE- Instituto Brasileiro de Geografia e Estatística. Produção agrícola. Disponível em: $<$ http://www. ibge.gov.br>. Acesso em: 20 maio 2011.

INSTITUTO DE ECONOMIAAGRÍCOLA. Produção e número de plantas de videira no Estado de São Paulo. Disponível em: <http:// www.iea.sp.gov. br.>. Acesso em: 25 fev. 2011.

MALO, S.E. Nature of resistence of Okinawa and Nemaguard peach to the root-knot nematode Meloidogyne javanica. Proceedings of the American Society for Horticultural Science, Alexandria, v.90, p.39-46, 1967.

MARTINS, F. P.; PIRES, E. J. P.; HERNANDES, J. L.; TERRA, M. M.; MOURA, M. F.; CIA, P. Uva. In: DONADIO, L. C. História da fruticultura paulista. Jaboticabal: Sociedade Brasileira de Fruticultura, 2010. p. 304-368. 
MEDEIROS, A.R.M. de. Cultivo do pessegueiro. Pelotas: Embrapa Clima Temperado, 2005. Disponível em: <http://sistemasdeproducao.cnptia.embrapa. br/FontesHTML/Pessego/CultivodoPessegueiro/ index.htm>. Acesso em: 2 fev. 2011.

PEREIRA, F. M. Produção de pêssego em regiões de clima tropical e subtropical. Revista Brasileira de Fruticultura, Jaboticabal, v. 25, n. 2, 2003.

PEREIRA, F. M.; MAYER, N. A.; CAMPO DALL'ORTO, F. A. Rigitano: nova cultivar de umezeiro para porta-enxerto de pessegueiro. Revista Brasileira de Fruticultura, Jaboticabal, v. 29, n. 1, p. 171-175, 2007.
TECCHIO, M. A.; TERRA, M. M.; CIA. P.; PIRES, E. J. P.; MOURA, M. F.; SANCHES, J.; BENATO, E. A.; HERNANDES, J. L.; VALENTINI, S. R. T.;

SIGRIST, J. M. M. Efeito do ácido naftalenoacético e do cloreto de cálcio na redução das perdas pós-colheita em uva 'Niagara Rosada'. Revista Brasileira de Fruticultura, Jaboticabal, v. 31, n. 1, p. 53-61, 2009. 